\title{
The Failure of Professional Self-Regulation: The Example of the British Veterinary Profession
}

\author{
Eddie Blass \\ University of Hertfordshire, United Kingdom
}

\begin{abstract}
This paper argues the case for professional bodies to lose their right to self-regulate wholly within their membership. Using the example of an analysis of six cases that were reported to the Royal College of Veterinary Surgeons (RCVS) as cases of false certification in the last 3 years, this paper demonstrates that self-regulation allows moral integrity to be sacrificed at the expense of economic imperatives, and individual judgements to be preferenced over fair process and procedure. Five of the six cases presented in this paper were upheld by the professional body and the sixth was dismissed and went through the British legal system instead. Narrative analysis of the case reports reveals a lack of consistency in the professional body's analysis of motive, causal connections, responsibility regarding implications and their role as either purveyor of standards or mentor to the profession, which has resulted in anomalies that leave the profession in disarray. By failing to act 'professionally' itself, this paper argues that the RCVS itself has undermined five of its own ten guiding principles, and hence can no longer regulate its own membership. The need for professional regulation beyond those provided by the professions themselves is presented if only by the inclusion of lay-people in professional disciplinary hearings.
\end{abstract}

\section{Keywords}

Professional bodies, self-regulation, moral integrity, economic imperatives, British legal system

\section{Introduction}

Since the 1990s the privileged position of the professional has started to be questioned. The accounting profession were one of the first to come under what I would call 'professional scrutiny'; that is, being questioned with regard to the application of quality standards and self-governance, with the attention of media, government and society eroding the reverent position of elite esteem. Cooper et al (1994) note that a number of scandals cast doubt upon the established independence and trustworthiness of the accounting profession and they highlight the continual engagement of those involved in maintaining status and regulation with significant others such as politicians, civil servants, journalists and academics, who have their own agendas. The concept of a professional stems from a power discourse based on claims to self-regulation, independence and expertise, reliant on the shifting material conditions upon which the stability of this ideology depends. Frankel (1989) argues that the profession as an institution in itself serves as a normative reference group for its individual members

Copyright (C) 2010 Victoria University. This document has been published as part of the Journal of Business Systems, Governance and Ethics in both online and print formats. Educational and non-profit institutions are granted a nonexclusive licence to utilise this document in whole or in part for personal or classroom use without fee, provided that correct attribution and citation are made and this copyright statement is reproduced. Any other usage is prohibited without the express permission of the publisher. and through its various codes of ethics and practice clarifies the norms that ought to govern professional behaviour. He identifies three types of codes: aspirational; educational and regulatory. This paper questions whether codes which are represented to the public as regulatory are actually being treated as aspirational by professional bodies in their practice of selfregulation. Professional bodies create a 
balance against state dictat, however this position is open to abuse when they themselves are both self regulating and concerned with promoting their own self-interest. This is particularly the case in professions where the practices are very lucrative. In a business world where social and ethical issues are becoming increasingly important to consumers and society, the continuation of self regulation of lucrative professions needs to be considered.

The debate surrounding the definition of 'professional' can be categorised into four areas: the definitional controversy; the debate about the process and implications of market closure and social closure; the ethnographies of professional work; and the histories of particular professions (Neal \& Morgan, 2000), none of which may be mutually exclusive. For example, Abbott (1988) exemplifies the sociological perspective which focuses on the role of the professional in society. He also questions the way in which groups control access to knowledge and occupations, viewing professions as a form of occupational control within society, such that not everyone is licensed to practice as a professional in their field, moving into the second area of debate - that of market and social closure. Lawrence (2004) also focuses his attention on group membership seeing the concept of membership as being the base of legitimate participation in a social arena. Membership in professional fields is demarcated by specialised knowledge safeguarded formally by universities and professional associations and informally by culturally entrenched understanding of the meaning of professional work. Indeed the Royal College of Veterinary Surgeons (RCVS) guide to professional conduct states 'foster and endeavour to maintain good relationships with your professional colleagues' as one of its 10 guiding principles (RCVS, 2008a). The danger is that this becomes somewhat incestuous. Koehn (1994) argues from a historical perspective that 'professional practices qualify as morally legitimate because, and to the extent that, they are structured to merit the trust of clients....Professions are not mere ideologies but inherently ethical practices.'

Eraut (2000) focuses his definition of professional around the ideological aspect of what professionalism should be about, taking a more normative perspective. He argues that there are three central features of the ideology of professionalism: a specialist knowledge base; autonomy, and service. He is clear about separating the professional themselves from the professional body, a rhetoric that is difficult to enact in reality as professional bodies are themselves constituted by and representative of the group of individual professionals. By separating the professional from the regulating body, the establishment of the professional as a professional becomes somewhat unsound.

The concept of 'the Professional' was traditionally beyond reproach. The fact that the professions were given the right to self-govern by Royal Charter, and were legislatively established meant that their history was one of elite esteem and reverence by society generally. It was believed that only the professionals themselves have the expertise to regulate their peers. Quinn et al (1996) see professionalism as stemming from a knowledge base. They suggest that the true professional commands a body of knowledge - a discipline that must be updated constantly. This is represented within most professions through the idea of 'continuous professional development' (CPD), with some professional bodies going so far as to state a minimum requirement of CPD per year. Another example of the RCVS's 10 guiding principles is to 'maintain and continually develop your professional knowledge and skills' (RCVS, 2008a).

Arguably, the idea of the professional as being the backbone of society is under threat. Dent \& Whitehead (2002) see a shift in how professionalism is measured from the perspective of morality and ethics shifting towards a regulatory perspective. They view the professional as someone who was traditionally trusted and respected; an individual who was given class, status, autonomy, and social elevation, in return for safeguarding our well-being, and they apply their professional judgement on the basis of a benign moral or cultural code. Now, however, they observe an audit-based measure of professionalism as agencies and organisations are being held to account by measuring process and performance and enforcing a regulatory framework. This has arguably arisen from the moral dilemmas the professional's face when balancing their interest in making money with their ethical responsibility as a professional.

Power and economic discourses interact clearly here. A survey of Industrial Hygienists in America found the greatest reason for ethical misconduct was economic pressures, followed by on-the-job 
pressures (Burgess \& Mullen, 2002). Competitive pressures and the need to meet client demands were recognised by Nelson (1984) as leading solicitors to adopt what he called 'ethical tunnel vision' as far back as the 1980s. Davies (2005) notes that the current regulatory system for solicitors is built around an older version of professionalism, when the profession served individual, non-influential clients rather than large, powerful corporate entities. The legal profession in the UK, having been criticised for its handling of professional complaints on a number of occasions ${ }^{1}$, has devolved its regulatory body from the Law Society to the Solicitors Regulatory Authority in a move to retain its independent professional status and avoid independent regulation.

Friedson (1986) specifically focuses on the power relationships that professionals carve out within society, viewing professionals as the agents of formal knowledge. In questioning the difference between professionals and amateurs, Friedson reflects on how people in a society determine who is a professional and who is not; how they make or accomplish professions by their activities and what the consequences are for the way in which they see themselves and perform their work. This external esteem is a source of power and reflected in many professional codes of conduct, for example 'upholding the good reputation of the veterinary profession' is another of the RCVS's ten guiding principles of professional conduct (RCVS, 2008a).

The question arises as to whether or not such power leads to a sense of authenticity amongst professionals. Kosmala \& Herrbach (2006) examined the way in which professionals behave in their workplace according to the expectations of their peers and other societal groups, and concluded that professionals are playing their role rather than being, such that differences can arise between the image professionals portray and who they really are. This is arguably what led to the scandals within the accounting profession and the devolvement of regulation within the legal profession to an alternative regulatory body to the body which represents the professionals themselves.

Friedson in his later work (1994) questions the extent to which there is a domination of professional power in Gramsci's idea of intellectual hegemony, or whether there is a steady decline of professional power that he describes as deprofessionalisation, proletarianization, rationalization, bureaucratization or corporatization. He views the professions as having no intrinsic resources other than their command over a body of knowledge and skill that has not been appropriated by others. Hence he questions whether they are losing their position of prestige and trust in society and within large organisations, are they losing their autonomy and control? At the crux is the question of whose interest is the knowledge being used for.

This paper argues that professionals are indeed losing their 'professional power' but that this is not due to proletarianization, rationalization, bureaucratization or corporatization, but rather to the 'deprofessionalisation' of the 'professional body' - that which exists to maintain the professions prestige and trust in society, and autonomy and control. It is the balance of power between the individual and the professional body that is undermining the concept of the professional in current times, as the collective appears to exploit the moral weaknesses of the individuals rather than their strengths. Macdonald (1995) argues that individuals construct their careers and professional identity as social participants in the professional body, noting that the balance between personal integrity and group monopoly in an economic system is an uneasy one. The balance between upholding the 'being' of a professional and the moral responsibilities that comes with that, and 'promoting the profession' and the income generation possibilities that attract people to the profession is a difficult balance to maintain within a professional body. This paper argues that the two should be separated out, to keep the business promotion from the business regulation, and place the professional bodies within the regulatory frameworks that apply within other regulated industries and sectors such as financial services.

The concept of professional bodies self-regulating their profession dates back to the $19^{\text {th }}$ Century, with the clergy, lawyers and doctors carrying the status of the 'original' professions. Self-regulation manifests itself in a number of formal and informal mechanisms. The formal mechanisms are the

The Fabian Society published a call for independent regulation in 1998, followed by the Lord Chancellors Office in 1999 and 2002 , leading to the Department for Constitutional Affairs enquiry chaired by Sir David Clementi reporting in 2005. 
codes of practices, rites of entry, and processes put in place to manage the professional membership. The informal mechanisms are shaped by professional etiquette and ethics that shape the formal mechanisms. Such etiquette suggests within the professions that it is wrong to criticize a fellow professional's behaviour (Rosenthal, 1997). As such professional bodies have increasingly come under public scrutiny for their failure to self regulate. In the 1990s a number of high profile misconduct cases within the medical professions resulted in the 1999 NHS Bill giving more widespread powers to the National Health Service (NHS) to make changes in the machinery of regulation of the health professions (Davies, 2000).

The Veterinary Profession in the UK, through its professional body The Royal College of Veterinary Surgeons, provides us with a perfect example of a professional body that is failing at its own selfregulation, losing the balance between integrity and economics. Through some very public and appropriate evidence stemming from a number of recent disciplinary cases, they have failed to take appropriate action in some cases and in others their action has been unjustifiable, as they continually confuse their responsibility to the public with regard to market and social closure, they abandon the histories of their professional colleagues, and leave the definition of their professional boundaries to the law courts who have been involved in a number of cases which should have been dealt with within the profession itself. This has left the RCVS as no more than an administrative entity offering a bureaucratic service to a beleaguered profession.

\section{Methodology}

As with all forms of discourse analysis, it is important to be reflexive with regard to the author's interpretation, to identify the lens that the paper has been conceived through. As a former member of faculty in a Business School, and now an academic in a School of Education specialising in 'Professional Learning' the author has already researched and published in the field of defining professionalism and professional learning as bounded entities (see, for example, Blass, 2007). Having owned horses for many years, the author has been interested in the operations of the veterinary profession and the extent to which business and professionalism contrast. Ask any horse owner and they will tell the first question every vet asks when attending to a horse is 'is the horse insured?' The financial stability of the client should be established when registering with the practice, not when the horse needs diagnosing and treating. However, the diagnosis process and treatments vary according to the answer to this question suggesting the business and professional boundaries are often blurred. Finally, the author was involved in an incident with a vet over the purchase of a horse which she believed to be false certification but the RCVS threw the case out without even considering it before a disciplinary committee. The case went to the courts as a professional negligence case and lost. The author started an enquiry through a rigorous exploration of other cases into why these were the outcomes and carried out a narrative discourse analysis of other cases of false certification reported to the disciplinary committee for a comparison.

This paper uses what Lee (2000) calls 'unobtrusive research methods'. That is, the data used for analysis was not directly recorded for the purposes of the investigation, but rather was freely available recordings of occurrences within the profession as reported on the RCVS website, the All England Law Reports, and other media reporting and correspondence that occurred at the times of the incidents in question. Marx (1984) argues that researchers should make better use of information generated by investigative, legislative and judicial bodies, although the data is not unproblematic as witnesses will have been selected for a reason and hence may not be truly representative. As such, they are treated as narratives, as stories of what the cases involved, outlining a sequences of events that occurred and were reported for a particular purpose. It is the story of the events that is of interest rather than the way in which they reported and, as such, it is the narrative that is the focus of the analysis rather than words themselves. The data therefore selected for this analysis were the reports and findings of the RCVS disciplinary committee and their judgements as published on their website, and the correspondence to and from the RCVS including the case and defence presented in the author's case and findings from the court judgement. All documents relating to the latter case are in the public domain as they were presented to the courts. All this data was freely available in the public domain. In addition they were selected because of their capacity to illustrate the issue concerned, the sentiment 
attached to it and the affective states that surround it, as outlined by Webb (1981) in his generative taxonomy of unobtrusive measures.

The data has been analysed using a meso-discourse analysis of narratives, looking at each reported incident to unpack the sequencing and patterning of events and the meaning-making that surrounded them. A template was created to record the stories with particular focus being placed on the following elements which were reported in all the incidents:

a) attributing motives of the defendants with regard to both their actions at the time and the way they approached their hearings;

b) causal connections with regard to outcomes for the animals concerned and the parties involved;

c) responsibility of the vets to the profession;

d) the respective roles of the RCVS and law courts.

The cases were selected as they are all the cases within the 3 year period 2006-2008 inclusive which address the issue of false certification according to a scrutiny of the cases listed on the RCVS website as having been considered by the committee. The issue of 'false certification' is stated as one of the guiding principles of the veterinary profession and one of three named offences which amount to gross professional misconduct. As such, it should be a core principle being upheld through the process of self-regulation.

\section{Results}

The details of the cases are presented in turn before a comparison table is presented.

Case No 1: In September 2006, Mr Lyndon Basha was found guilty of four charges of disgraceful professional conduct relating to mistreatment of animals and false certification by signing an insurance form for an uninsured animal as if it were another insured animal. Mr Basha qualified as a vet in Queensland and was exceedingly apologetic for his errors and fully admitted responsibility and remorse to the committee. A number of animals were clearly mistreated (and arguably suffered) as a result of Mr Basha's actions and an insurance company was involved in a false claim. The disciplinary committee postponed judgement for 2 months pending an outline development plan, and then a further 2 years for this plan to be implemented to ensure that Mr Basha was redressed his issues of incompetence during this time through CPD, supervision by mentors and other activities agreed with the committee. At the end of the two year period, the disciplinary committee held that in respect of the clinical charges 'Mr Basha is now a competent veterinary surgeon and has decided to take no further action against him. However, the committee takes the issue of false certification very seriously and therefore has decided to issue a reprimand to Mr Basha in respect of his conviction of the Insurance Certification charge.' (RCVS, 2008b)

Case No 2: In January 2007, Mr Alan Walker was found guilty of two charges of professional misconduct relating to the mis-dating of vaccinations in race horse passports. Mr Walker admitted to his offence and noted that it had been wrong, but offered a justification as to why this was not gross misconduct. No horse appears to have suffered as a result of his action, and neither did any owner. $\mathrm{He}$ had simply failed to comply with the Jockey Club's rules. Mr Brian Jennings, Chairman of the Disciplinary Committee, said: "We regard any false certification as being an extremely serious matter because it weakens the confidence of the public and damages the integrity of the profession. We acknowledge in Dr Walker's favour the frankness of his admission of the facts, but consider that he ought to have known the significance of his actions, which have fallen far short of those which are expected of a veterinary surgeon. The only appropriate course is to remove Dr Walker's name from the Register." The Committee also noted Mr Walker's seniority within the profession and his particular standing and expertise within the racehorse community, regarding this as all the more reason for such a severe punishment. This case then went to the law courts and the Privy Council heard an appeal against the decision of the committee on 30 October 2007. While upholding the charge, it reduced the sentence to a six month suspension as the grounds for the severity of punishment were unfounded. (RCVS, 2007a) 
Case No 3: In June 2007, Mr Paul Hallum was suspended from the veterinary register for a period of two months for falsely certificating a horse as sound. The circumstances were peculiar in that the certificate had been requested for one purpose and used for another. In essence this was an issue of a vet dictating a letter over the phone and getting it sent out, signed on his behalf, without checking his records. Mr Hallum apologised profusely for his wrongdoing, fully admitting the error of his ways and outlined the steps he would take to ensure he did not repeat such an offence. It is unclear as to what the outcome for the horse was in this case, or indeed for the new owner as no evidence to this effect was presented in the findings. Mr Brian Jennings, Chairman of the Disciplinary Committee said: "We wish to make clear the importance and status of any document signed by a veterinary surgeon that another body might rely on."

Case No 4: In October 2007, Mr William Morris was removed from the veterinary register for false certification of a horse in a pre-purchase vetting examination. Chairman of the Disciplinary Committee, Mr Brian Jennings, said: "Members of the public are entitled to expect a member of the profession to act with integrity, probity and trustworthiness and any failure on the part of a veterinary surgeon to meet those high standards damages the public's perception of the profession." The disciplinary committee were sure that Mr Morris signed the certificate when he knew that there were signs of disease or abnormalities with this horse, despite the fact that the horse appears to have continued doing the job it was vetted for without any surgery or on-going treatment. Mr Morris defended his position, arguing that this was not a case of false certification, arguing (in writing rather than in person) that abnormal findings did not inhibit the horses use for the purpose it was vetted for, and that he had orally told the prospective buyers of the issue concerned. The disciplinary committee however held that "Members of the Public are entitled to rely on a certificate made by a veterinary surgeon without question. This is a cornerstone of the profession.... Such behaviour amounts to disgraceful professional conduct and will not be tolerated. It is therefore both appropriate and proportionate to remove Mr Morris's name from the Register."

Case No 5: In November 2007, Mr John Williams was removed from the veterinary register for false certification of horses being exported. Mr Williams claimed that the certification would be checked and countersigned by DEFRA by which time the certificate results would be available, and hence there had been no risk involved in his activities as the test results would be available by then, or the certificates would be revoked. Mr Williams admitted that his actions were wrong but justified them on the basis that they could/would be resolved within a matter of hours when the results came through. No animal suffered as a result of his actions, and no animal was exported that should not have been. Mr Williams therefore defended his actions as not being gross misconduct. Chairman of the Disciplinary Committee, Mrs Alison Bruce, said: "The Royal College of Veterinary Surgeons has always given a high priority to the maintenance of accuracy and truthfulness of veterinary certificates. Mr Williams gambled on the likelihood that the results would be negative. This can never be the basis for proper certification." Mrs Bruce concluded: "We have been invited to assess Mr Williams' character and, sadly, we assessed his attitude to certification as being either irresponsible, or cavalier, or both. In order to maintain public confidence in veterinary certification and to reinforce to the profession the importance of accurate certification ... we have no alternative but to instruct the Registrar to remove Mr Williams' name from the Register."

Case No 6: In April 2008, a Professional Negligence case was held in the High Court which was previously rejected by the RCVS under an earlier submission to the disciplinary committee for false certification. The argument put to the court was that the vet in question, Ms Sarah Randall, had signed a pre-purchase vetting certificate stating a horse was suitable for purchase for dressage without mentioning the fact that the horse had a de-nerving procedure in two legs. The procedure, according to the witness statements, desensitised rather than cured a career-ending condition known as proximal suspensory desmitis, rendered the horse illegal to compete under FEI rules in dressage, arguably (veterinary testimony differed) meant that a test of soundness could not be completed, made the horse uninsurable on those two legs, and could have a number of serious longer term implications for the horse's well-being which did actually result in the horse being retired due to recurrent issues from the de-nerving operation. Despite all of this and contrary to the line of argument adopted in the case of $\mathrm{Mr}$ Morris, the RCVS disciplinary committee did not consider the issuing of the certificate in this case to 
be false. The courts also felt that Miss Randall was not guilty of negligence as they believed her claims that she told the prospective buyer orally. In setting down his judgement on the completion of pre-purchase certificates in the High Court, Judge Seymour noted 'As long as the relevant information is communicated clearly and comprehensibly to the Client I see no reason why it needs to be communicated or confirmed in writing. The Client does not need to be told twice what he has already been told, and understood, once.' This renders any certification procedure as valueless as a vet need simply now claim that they told the owner/buyer verbally.

The table presents the RCVS principles breached, the circumstances that caused the complaint to be made, the outcomes for the injured parties including animals, owners and insurance companies, the role the RCVS has played in their carrying out of the hearing, the justification given by the veterinary surgeon concerned for their actions and the outcome of the disciplinary committee.

The ten guiding principles outlined for the veterinary profession as stated on the RCVS website and publications are that 'your clients are entitled to expect that you will:

a) make animal welfare your first consideration in seeking to provide the most appropriate attention for animals committed to your care

b) ensure that all animals under your care are treated humanely and with respect

c) maintain and continue to develop your professional knowledge and skills

d) foster and maintain a good relationship with your clients, earning their trust, respecting their views and protecting client confidentiality

e) uphold the good reputation of the veterinary profession

f) ensure the integrity of veterinary certification

g) foster and endeavour to maintain good relationships with your professional colleagues

h) understand and comply with your legal obligations in relation to the prescription, safe-keeping and supply of veterinary medicinal products

i) familiarise yourself with and observe the relevant legislation in relation to veterinary surgeons as individual members of the profession, employers, employees and business owners

j) respond promptly, fully and courteously to complaints and criticism' (RCVS, 2008a). 


\begin{tabular}{|c|c|c|c|c|c|c|}
\hline Case & $\begin{array}{l}\text { Principles } \\
\text { Breached }\end{array}$ & $\begin{array}{l}\text { Causal } \\
\text { Connections }\end{array}$ & $\begin{array}{l}\text { Responsibility/ } \\
\text { Implications }\end{array}$ & $\begin{array}{l}\text { Role of } \\
\text { RCVS }\end{array}$ & $\begin{array}{l}\text { Justification } \\
\text { Given }\end{array}$ & Outcome \\
\hline 1 & $\mathrm{~A}, \mathrm{C}$ and $\mathrm{F}$ & $\begin{array}{l}\text { Multiple } \\
\text { complainants }\end{array}$ & $\begin{array}{l}5 \text { animals suffered. } 1 \\
\text { false insurance } \\
\text { claim. }\end{array}$ & Mentor & $\begin{array}{l}\text { Remorse for } \\
\text { errors }\end{array}$ & 2 years $\mathrm{CPD}$ \\
\hline 2 & $\mathrm{~F}$ & $\begin{array}{l}\text { Complainant } \\
\text { in dispute \& } \\
\text { used } \\
\text { complaint as a } \\
\text { bargaining } \\
\text { tool }\end{array}$ & $\begin{array}{l}\text { No animals suffered. } \\
2 \text { horses needed to } \\
\text { restart their } \\
\text { vaccinations. }\end{array}$ & $\begin{array}{l}\text { Upholder } \\
\text { of } \\
\text { standards }\end{array}$ & $\begin{array}{l}\text { Common } \\
\text { practice of } \\
\text { leeway }\end{array}$ & $\begin{array}{l}\text { Struck off; } \\
\text { Privy Council } \\
\text { reinstated after } \\
6 \text { month ban }\end{array}$ \\
\hline 3 & $\mathrm{~F}$ & $\begin{array}{l}\text { Purchaser of } \\
\text { horse relied on } \\
\text { certificate } \\
\text { seller had } \\
\text { requested for } \\
\text { other purposes } \\
\end{array}$ & $\begin{array}{l}\text { Horse purchased that } \\
\text { would otherwise not } \\
\text { have been. Monetary } \\
\text { loss. }\end{array}$ & $\begin{array}{l}\text { Upholder } \\
\text { of } \\
\text { standards }\end{array}$ & $\begin{array}{l}\text { Letter dictated } \\
\text { over phone } \\
\text { used as } \\
\text { certificate. } \\
\text { Apology given. }\end{array}$ & 2 month ban \\
\hline 4 & $\mathrm{~F}$ & $\begin{array}{l}\text { Purchasers of } \\
\text { horse }\end{array}$ & $\begin{array}{l}\text { No loss. Horse is still } \\
\text { performing at level } \\
\text { for which it was } \\
\text { vetted without } \\
\text { treatment or surgery. }\end{array}$ & $\begin{array}{l}\text { Upholder } \\
\text { of } \\
\text { standards }\end{array}$ & $\begin{array}{l}\text { Condition did } \\
\text { not affect use } \\
\text { hence not on } \\
\text { certificate. }\end{array}$ & Struck off \\
\hline 5 & $\mathrm{~F}$ & DEFRA & $\begin{array}{l}\text { No loss or harm to } \\
\text { animals. Certificates } \\
\text { were however relied } \\
\text { upon by a third party } \\
\text { for a period of time. }\end{array}$ & $\begin{array}{l}\text { Upholder } \\
\text { of } \\
\text { standards }\end{array}$ & $\begin{array}{l}\text { Certificates } \\
\text { signed for } \\
\text { expediency } \\
\text { reasons. If not } \\
\text { ok, would be } \\
\text { called back at } \\
\text { docks. }\end{array}$ & Struck off \\
\hline 6 & $\mathrm{~F}$ ? & $\begin{array}{l}\text { Purchaser of } \\
\text { horse }\end{array}$ & $\begin{array}{l}\text { Horse had to retire } \\
\text { after injury resulting } \\
\text { from lack of } \\
\text { knowledge of prior } \\
\text { condition. Financial } \\
\text { loss. False insurance. }\end{array}$ & None & $\begin{array}{l}\text { Purchaser was } \\
\text { told orally of } \\
\text { condition. } \\
\text { Previous } \\
\text { history should } \\
\text { not go on } \\
\text { certificate. }\end{array}$ & $\begin{array}{l}\text { Case } \\
\text { dismissed } \\
\text { without } \\
\text { hearing }\end{array}$ \\
\hline
\end{tabular}

Table 1: A comparison of False Certification cases in the UK Veterinary Profession 2006-2008.

\section{Discussion}

It is difficult to see at face value, regardless of how dishonest the RCVS may think that the purchasers may have been - although this proved irrelevant in case number 2 - how this last situation (case 6) differs to that for which the vet in case number 4 was struck off. Indeed, Miss Randall's certificate was also used to falsely insure the horse, which amounts to the reliance of another party for which case number 5 was struck off, and her testimony in court notes how she remembered the vetting in her memory and did not make any notes at the time, and other breaches of the British Equestrian Veterinary Association's (BEVA) guide to pre-purchase examinations, which would make her case more aligned to case number 2's lack of following due protocol resulting in his suspension.

However, in this final case, the RCVS chose to do nothing. The result of the law courts therefore stands that there 'is no reason why it [relevant information] needs to be communicated or confirmed in writing' provided it has been communicated clearly and comprehensibly to the Client orally. Messrs Morris, Williams and Hallum should take note. They ought to declare that they told their respective parties orally, and that is why their findings were not on the certificates they issued - the RCVS can do nothing but accept this now as a judgement. This is particularly so as the case of Miss Randall was re-presented to the RCVS post the trial for further scrutiny on the basis of Miss Randall's testimony only as this amounted to 'new evidence', and the RCVS again dismissed it. 
So where exactly does this leave the veterinary profession? In the early days professional regulation was presented as a means of protecting the public; we are now seeing significant reversal (Davies, 2000). By examining these six cases we can see that the RCVS has not acted consistently with regard to maintaining the integrity of the profession by confusing the motives, causal connections and responsibilities of both the vets involved and their own role. In a number of these cases the motives of the complainants have been called into question - in particular in Walker and Hallum, and possibly in Randall. In the first two these mitigating factors were ignored. In Randall and Basha the RCVS clearly took the view that the motives of the vets had been so admirable that any conduct failing could be ignored or rectified. In Walker, Williams and Morris, the motivations of the vets involved were questioned and felt to be lacking by the RCVS and hence they were punished accordingly. Remorse appears to play a bigger part in the decision process than logical reason. Indeed, in a further case (M William Baird) which was not a false certification case and hence has not been analysed in this paper, a vet was reinstated a year after being struck off simply because he e-mailed a letter of remorse to the RCVS, promising not to do it again (he refused to make a home visit out of hours).

By focussing on the motivation of the vets - the economic imperative, rather than the actual misconduct that occurred - the moral imperative, and by being drawn into personalities - the ethnographies within the profession, the RCVS has failed to act responsibly in its role of purveyor of standards. Professional standards are set as such because they are the minimum below which people cannot stray and remain within the profession. That is their raison d'etre. Because the RCVS has been inconsistent in their application of standards, the British legal system has become involved. This, in itself, is evidence of its lack of ability to self-regulate. The result can only be interpreted as a disaster for the veterinary profession as a whole. It's professional body can no longer impose sanctions for false certification that it wishes; and indeed any vet can now avoid a false certification offence by saying 'but I told them verbally.'

By taking on the role of mentor to the profession rather than upholder of the professional standards, the RCVS has issued 2 year CPD orders in a number of cases to allow people to undergo the necessary development to get themselves back up to the standard required of a competent veterinary surgeon. This is not what you would expect of the body that is set up to maintain standards. I would hate to be operated on by a surgeon that I later found out was just starting two years of refresher training to make sure he really was competent enough to operate on me. Why should this be different for any other profession. One of the core elements that identifies a profession in the literature is the control of access to the knowledge and occupation. As soon as a profession opens the door to people being allowed to obtain that standard whilst in the profession, it has dumbed down its own standards, knowledge and occupation.

Davies (2000) views late twentieth century governments as trying to redress the imbalances occurring in professional self-regulation through reconstituted models and development of social policy that regulates persons, programmes and policy rather than the profession as a whole. This has remained with the professional bodies as successive governments have avoided this final step of putting in place intermediary bodies. Thus far, government intervention in professional standards have been restricted to the areas of health and social care as these are their core areas of service provision, and key targets for the media. As a nation of animal lovers, the veterinary profession may not be shielded from the media indefinitely.

Why has the RCVS been so inconsistent in its duty to perform its responsibilities? It might be interesting to do a diversity analysis on the judgements given out by the disciplinary committee. This is not an area of concern or interest in this paper, but it is interesting to note that now struck-off Messrs Morris, Walker, and Williams are all white males. Randall is a white female and was not even considered by a disciplinary panel. Basha originally qualified overseas. The economic and power discourses may relate to forms of institutional discrimination within the system in that there are higher expectations placed on British white males than others? Indeed, the Privy Council ruled that the RCVS had been overly harsh on Walker because he had such high standing in the veterinary community, and hence they thought he should be treated more harshly. It would appear that emotions have dominated logical application of standards throughout these cases. Baumeister \& Heatherton (1996) identified misregulation as occurring due to false assumptions or misdirected efforts due to unwarranted 
emphasis on emotions. They claim that underregulation occurs because of deficient standards, inadequate monitoring or inadequate strength. The RCVS could be argued to be guilty of both misregulation and underregulation in its application of false certification standards.

Alternatively, there may be some form of 'old boys club' in operation, as who trains and mentors whom may come into play. The names of those who sit on the Disciplinary Committees and consider the cases are not made public so any relationship that those hearing the case may have to the person being considered is not available for public scrutiny. This may not be the case, but the lack of transparency raises questions. If independent lay-people were included, as is the practice in industrial tribunals, then this issue would not arise.

\section{Conclusions}

What is clear is that the lack of consistency and engagement by the RCVS in issues that it should have had a firm and clear message on has resulted in the law courts taking away much of their autonomy and responsibility for the profession. As such, they are now a profession that is in trouble, as their membership will be well aware that the boundaries within which they can officiate have been severely limited. If we go back to their own ten guiding principles; the case of Randall practically wipes out the principle of false certification, which is also one of the three stated reasons for a finding of gross misconduct; the case of Walker wipes out the RCVS's ability to protect the integrity of the profession; and the case of Basha wipes out the need for CPD as you can always do it after you've fallen short of performance targets. Indeed, if you take the ten guiding principles literally, the RCVS has fallen short of at least five of them itself in its handling of professional misconduct. I still can't help but wonder what it was that I did that was so wrong in the Randall case that has led to such a mess?

By basing its judgements on the remorsefulness of the vets concerned (cases $1 \& 3$ ) rather than facts of the cases, their implications for the animals (case 1 in particular), owners and third parties concerned, such as insurance companies, DEFRA and racing bodies (see cases 2, 3 and 5 in particular), and confusing their role as a purveyor of standards and mentor to the profession (case 1 in particular), the RCVS has handed the mandate for occupational control to the courts which undermines its professional status according to Abbot's conceptualisation of professions (1988). It has brought into question the morality and ethics regulating the profession through its inconsistent application of its own guiding principles (a, c and $\mathrm{f}$ in particular) which negates Whitehead's (2002) view of professionalism, and undermines the trust of the public in the profession outlined by Koehn (1994) and Dent \& Whitehead (2002). By allowing Basha to effectively retrain while on the job they have undermined the knowledge base outlined by Quinn et al (1996) and Eraut (2000).

False certification by its very nature is the guiding principle most likely to be compromised by the call of monetary gain within the profession. It is the one through which financial gain can be obtained and it is the one that is most open to exploitation. The actions of their own Disciplinary Committee with regard to the professional cornerstone of false certification have resulted in the RCVS undermining its own professional status and integrity. Quite how they are to recover from this position is questionable. Certainly the operations, actions and judgements of the committee require greater scrutinisation within the RCVS itself if Gramsci's concepts of deprofessionalisation and bureaucratization (Friedson, 1994) are to be held in check and the profession is to regain the ground it has lost.

After being the subject of public scrutiny on a number of occasions, The Law Society recognised the difficulty in serving the interests of promoting the profession while maintaining independence in regulating the profession and hence separated its regulatory board into an independent entity in January 2007, the Solicitors Regulating Authority (SRA).

The ability to self-regulate is dependent on the ability to be impartial and objective in the application of the regulations, standards and ethical codes that govern the profession. This is a difficult task for anyone to undertake within a profession, as it is human nature to empathise, even sympathise, with the situation a fellow professional may find themselves in. This, however, does not benefit the profession or wider society that the professional body is empowered to protect and serve. The introduction of laypeople on to disciplinary committees may be one way of starting to redress the imbalance. Hiving off the regulatory sector of the profession to a separate body, as per the lawyers above, may be another. 
There are many ways that professional bodies can re-establish their credibility and trustworthiness, and transparency is paramount. The Royal College of Veterinary Surgeons is unlikely to be alone in its difficulties to self-regulate, indeed the accountants, medical professions and legal professions have already made adjustments to their regulatory processes in order to ensure a better regulatory regime. Self-regulation of professions under the economic pressures of modern life is clearly not working. Vets operate both as businesses and as professionals

It is simply a question of time before something triggers enough of a public outcry to make the so called 'professions' question their practice. In the nature of professionalism itself and the ethical basis of professionalism, it would be more appropriate if professional bodies undertook this audit themselves before any government or media pressure ensues. This might allow the professions to reclaim their position of esteem in society and the trustworthiness associated with self-regulation. The veterinary profession has more than enough evidence on which to examine its own practice now. While the RCVS may continue to have an important role to play in attracting people to the profession and promoting the business of veterinary science, it also needs to recognise that it can no longer self regulate in matters where business practice and professional ethics and standards clash.

\section{References}

Baumeister, R. F. \& Heatherton, T. F. 1996. Self-Regulation Failure: An Overview. Psychological Inquiry, 7(1):1-15.

Blass, E. 2007. Professional Learning and Work-Based Learning: Divergence in Rhetoric, Convergence in Reality. International Journal of Learning. 14(9)

Burgess, G. L. \& Mullen, D. 2002. Observations of Ethical Misconduct among Industrial Hygienists in England. American Industrial Hygiene Association Journal, 63:151-155.

Cooper, D., Puxty, T., Robson, K. \& Wilmott, H. 1994 The Ideology of Professional Regulation and the Markets for Accounting Labour: Three Episodes in the Recent History of the UK Accounting Profession. Accounting, Organisations and Society, 19(6): 527-553.

Davies, C. 2000. The Demise of Professional Self-Regulation: A moment to mourn? In Lewis, G., Gewirtz, S. \& Clarke, J (Eds) Rethinking Social Policy. Thousand Oaks: Sage Publications.

Davies, M. 2005. Solicitors - the last twenty years of self-regulation? Professional Negligence, 21(1): 3-26.

Dent, M. and S. Whitehead (2002). Managing Professional Identities. London, Routledge.

Eraut, M. (2000). "Non-formal learning and tacit knowledge in professional work." British Journal of Educational Psychology 70: 113-136.

Friedson, E. (1986). Professional Powers: A study of the institutionalization of formal knowledge. Chicago, Chicago University Press.

Friedson, E. (1994). Professionalism Reborn: Theory, Prophecy and Policy. Cambridge, Polity Press. Koehn, D. (1994). The Ground of Professional Ethics. London, Routledge.

Kosmala, K. and O. Herrbach (2006). "The ambivalence of professional identity: On cycnicism and jouissance in audit firms." Human Relations 59(10): 1393-1428.

Lawrence, T. B. (2004). "Rituals and Resistance: Membership Dynamics in Professional Fields." Human Relations 57(2): 115-143.

RCVS. 2008a. RCVS Guide to Professional Conduct. Available at http://www.rcvs.org.uk/Templates/Internal.asp?NodelD=89642 (accessed 2/11/08).

RCVS. 2008b. Final Decision of the Disciplinary Committee (Mr Lyndon Basha). Available at http://www.rcvs.org.uk/Shared ASP Files/UploadedFiles/rcvs/84C05FCF-A5EB-4233-81F24C01334A6621 Basha finaldecision.pdf (accessed 8/11/08).

RCVS. 2007a. Judgement of the Disciplinary Committee (Dr John Alan Walker). Available at http://www.rcvs.org.uk/Shared ASP Files/UploadedFiles/9980638E-DD62-42FD-A9BA79199639CA63 walker,ja judgment.pdf (accessed 8/11/08).

RCVS. 2007b. Findings of the Disciplinary Committee (Paul Mark Hallum). Available at http://www.rcvs.org.uk/Shared ASP Files/UploadedFiles/EF5B37A4-B450-42A8-9E3787E937A0A6BC Hallum,PaulM findings.pdf (accessed 8/11/08). 
RCVS. 2007c. Judgement of the Disciplinary Committee (Mr Robert William Morris). Available at http://www.rcvs.org.uk/shared asp files/GFSR.asp?NodelD=97407 (accessed 8/11/08).

RCVS. 2007d. Judgement of the Disciplinary Committee (Mr John Williams). Available at http://www.rcvs.org.uk/Shared ASP Files/UploadedFiles/66535FF2-67F0-45AF-AEOD153302CD51B7 Williams,JohnB-judgment.pdf (accessed 8/11/08).

Rosenthal, M. 1997. Promise and Reality: Professional self-regulation and 'problem' colleagues. In Lens, P \& van der Wal, G. (Eds) Problem Doctors: a conspiracy of silence. IOS Press.

Webb, E. J., Campbell, D. T., Schwartz, R. D., Sechrest, L. \& Grove, J. B. 1981. Nonreactive measures in the Social Sciences. Dallas: Houghton Mifflin. 